\title{
Information Sharing in Socio-Technical System Demonstration Tests: Using Smart Grid System Demonstration Tests in Japan
}

\author{
Youngjae Koh
}

\begin{abstract}
This paper clarifies processes for promoting information sharing about results of socio-technical systems demonstration test which is conducted by firms who have different interest. By examining a smart grid system demonstration test in Kansai Science and Yokohama Cities in Japan, this paper has two major findings.

First, information sharing among firms on demonstration tests as a whole project has been promoted by the Project Promotion Council of the demonstration test which is coordinated by the regional government of the demonstration test area.

Second, in addition to the endeavor of firms who participated in demonstration test, the regional government of the demonstration test area works as a coordinator to promote information sharing between firms who participated in demonstration test and the Ministry of Economy, Trade and Industry (METI) of Japan who subsidize two-thirds of the demonstration test budget.

What became evident through this case study is for promoting information sharing among firms who have different interest should be consider establishing the information sharing organizational system and putting the regional government of the demonstration area as a coordinator on demonstration phase.
\end{abstract}

Index Terms - Information sharing among firms, smart grid system, socio-technical system, role of the regional government of the demonstration test area.

\section{INTRODUCTION}

This paper clarifies processes and the factor that make possible to promote sharing information among firms in a demonstration test of a smart grid system ${ }^{1}$, one type of environmentally-friendly socio-technical ${ }^{2}$ system in Kansai Science and Yokohama Cities in Japan. There are two reasons for analyzing information sharing processes on demonstration tests on socio-technical system.

First, socio-technical system innovation calls not only

Manuscript received August 15, 2013; revised September 30, 2013.

Youngjae Koh is with the Konan University, Hirao School of Management, Nishinomiya, Japan (e-mail: koh@center.konan-u.ac.jp).

${ }^{1}$ According to [1], a smart grid system is a next-generation transmission and distribution network in which the supply and demand sides of energy are connected with each other through a network using information technologies to optimally use energy, and a smart community is developed based on the smart grid system.

2 According to [2], a "socio-technical" is a concept in which independent people and technologies with different theories are connected with each other, and the socio-technical system is reformed by challenging two tasks simultaneously. The first task is to review the relationships among groups at every level in an organization. The second task is to reform business by improving productivity without incurring significant additional costs and to diffuse organizational improvement. innovative change at the level of technologies but also requires changing the relationship among stakeholders within a firm and among firms, however little is known about how the information sharing has been promoted among firms based on what forms of organization for changing that relationship [2].

If a means of sharing socio-technical system demonstration test results among multiple firms could be expounded, it would become possible to broadly introduce and diffuse such systems economically.

Second, from the view point of the uncertainty of the new investment about socio-technical system innovation, previous literatures argued that supporting from the government encourage firms' active participation however, little is known about the role of the government as the innovation promoting factor during the phase of demonstration test [3], [4].

How the information sharing promoted among firms based on what forms of structure during the socio-technical system demonstration test? And what kind of role has the government of the demonstration test area played during the demonstration test phase? These are the research questions considered in this paper.

In order to clarify the research questions of this paper, previous literatures on information sharing among firms participating in a socio-technical system are reviewed below.

\section{Previous Literatures}

As reference [5] argued, before the period of introduction and diffusion of socio-technical system, given that 1) the existence of a development purpose 2) development of requisite technologies suitable for the development purpose 3) implementation of a social demonstration test and 4) processes to accumulate and share data by creating a database or structure are necessary. Absence of steps for the sharing of the data concerning demonstration test would make a difficult in introducing and diffusing socio-technical systems.

This argument indicates changing relationships among stakeholders for developing new socio-technical system and constructs new information sharing way among them would not promote spontaneously, unless the organizational structure and some factors exit to promote it.

About active participation problems to produce environmental friendly products and a system, previous literatures indicate that support from the government to secure economic and technological superiority is the one of the factors to move to the development of products and a system [3], [6]. For example, incentives for the products and 
a system innovation, such as institutional support, tax breaks and regulations that have the room to continuous improvement of technology rather than locking in any particular technology is one of factors that active participating to the innovation. However, these literatures focused on products and a system that have been developed within individual firm. For developing new system with several products and systems, multiple firms' cooperation would be necessary.

About the encouraging factor that developing socio-technical system, reference [4] gives specific example to pay attention to the government's four roles as a leader to change firms' activity. The first method is referred to as self-governing. This method shows one example, where governments themselves invest in socio-technical systems that are the subject of demonstration tests, plan efficient energy consumption and tackle the challenges of recycling. The second method, called the governing by authority method, is one in which strategic plans or policies are created and the conduct of participating firms is altered in a way that aligns the firms with the plans or policies. Governing by provision, the third method, is an approach in which governments themselves become energy suppliers or the suppliers of waste recycling services. The fourth method, called governing through enabling, is a method in which government becomes the supporter of public promotion activities and educational programs to encourage the introduction and diffusion of socio-technical systems.

Including reference [4], there are literatures on the role of the government and regional government [7]-[9]. However, they are focused on introduction and diffusion phase of socio-technical system and there need the organizational structure to adjust information sharing among related firms to facilitate the development of a socio-technical system.

About the organizational form that constructs new relationships among firms and promote information sharing, previous literatures verified that it to be comprised of multiple levels hierarchies, and that cooperation among firms is required [9]-[13]. Though, these literatures are about the phase of the introduction and diffusion of socio-technical systems and not only the organizational structure for information sharing, it needs factors that promote information sharing.

Therefore this paper will clarify the information sharing processes among the related firms on socio-technical demonstration test with taking the position of explicating the role of the government in the processes of sharing information among firms during the phase prior to the introduction and diffusion of a socio-technical system.

The next section elucidates the process of sharing information about current situation of system development of demonstration test among firms and institutions in the development and demonstration test stage of a socio-technical system.

\section{CASE ANALysis}

\section{A. Demonstration Tests on a Smart Grid System in Japan}

At present, more than 400 smart-city plans have been advanced worldwide, in which information technologies are fully used to efficiently maintain and operate social infrastructure, including local energy, sewerage system, and traffic system [14].

Some smart-city plans adopt a smart grid system, in which power consumption in houses, offices, schools, and public facilities is visualized using monitors called smart meters to provide efficient power supply and demand [15].

In Japan, smart grid system demonstration tests have been performed in the cities of Yokohama, Kansai Science City ${ }^{3}$, Toyota, and Kitakyushu using government subsidies. These four cities are designated as demonstration areas for the Next Generation Energy and Social Systems Demonstration Project.

In these four demonstration areas, ordinary houses, commercial facilities including buildings, schools, and public facilities are investigated in demonstration tests. The detailed purposes of these four demonstration areas differ from each other because the types of industries activated in these demonstration areas differ.

This paper analyzes the cases of smart grid system demonstration tests on household sector in Kansai Science and Yokohama Cities.

\section{B. Program in Household Sector in Kansai Science and Yokohama Cities}

The program in Kansai Science and Yokohama City's household sector broadly divided into two parts. One is a demonstration test that is mainly used method of Electricity Demand and Response (hereafter, DR), another is involved installing a Home Energy Management System (hereafter, HEMS).

In Kansai Science City, Electricity DR is a demonstration test covering approximately 700 households using the DR method [16]. Participating households were divided into four groups and each group was assigned a different way to reduce the electricity use. The Group A (150 households) was assigned to use the method to visualize the electricity consumption using a tablet terminal and there were no request for demand constrain. For Group B (150 households) the visualization method used and a notification of request for power saving send to their table terminal. This request is about energy conservation that sent out the day before DR is implemented. For Group C and D (about 400 households), a mock variable power price menu, using points, and DR requests were implemented [17].

The demonstration test was implemented from 2012, mainly during the summer from July to September and in the winter from December to the following February in 2013, when demand for electricity increases. The main firms participating in the test were Mitsubishi Heavy Industries, Ltd., Mitsubishi Electric Corporation and Kansai Electric Power Co., Inc.

In Kansai Science City, the HEMS have been implemented in 14 newly-constructed buildings and such as the demand response demonstration test alignment with an energy use plan which was calculated based on the users' past energy consumption data have been carried out.

In Yokohama City the demonstration tests of HEMS for multiple dwelling houses and detached houses. The HEMS

Kansai Science City is lying astride Kyoto, Osaka, and Nara Prefectures. 
for multiple dwelling houses examines whether solar-electric power generation and the use of heat exhausted in the process of the power generation for hot-water production are simultaneously feasible. For this, the residential fuel cell cogeneration system (ENE-FARM in product name) is used. ENE-FARM simultaneously performs power generation and hot-water production using exhaust heat. This means if the consumption of either one rapidly increases, the supply-demand balance is lost. To prevent total energy efficiency from decreasing, it is important to indicate when either electricity or hot water can be used using an in-house display device. This demonstration test has been performed using 24 dwellings owned by Tokyo Gas Co., Ltd. and other 300 dwellings.

Another demonstration test on the HEMS uses more than 1,900 ordinary houses in Yokohama City. In the test, in an attempt to reduce electricity consumption, the DR is sent to an in-house display device, displaying current and past daily electric power rates as well as the sum of accumulated incentives on the device.

\section{Organization for Promoting Demonstration Tests in Kansai Science City}

The Next-Generation Energy and Social Systems Demonstration Project Promotion Council have organized in Kansai Science City in Sep. 2010 by cooperation of participating firms, institutions and the regional government. The organization formation is shown in Table I.

TABLE I: KANSAI SCIENCE CITY NEXT-GENERATION ENERGY AND SOCIAL SYSTEMS DEMONSTRATION PROJECT PROMOTION COUNCIL ${ }^{4}$

\begin{tabular}{|c|c|c|}
\hline \multicolumn{3}{|c|}{$\begin{array}{l}\text { Chair: Kyoto Prefecture } \\
\text { Vice Chair: Mitsubishi Heavy Industries, Public Foundation of Kansai } \\
\text { Research Institutes } \\
\text { Members: } 23 \text { other firms and organizations }\end{array}$} \\
\hline Promotion Committee & \multicolumn{2}{|c|}{$\begin{array}{l}\text { Public Foundation of Kansai Research } \\
\text { Institutes, } 17 \text { other organizations }\end{array}$} \\
\hline WG* & HEMS & Electricity DR** \\
\hline WG leader & OMRON & $\begin{array}{l}\text { Mitsubishi Heavy } \\
\text { Industries }\end{array}$ \\
\hline Participating firms & $\begin{array}{l}\text { Sharp } \\
\text { NEC }\end{array}$ & Mitsubishi Electric \\
\hline Supporting firms & $\begin{array}{l}\text { Kansai Electric Power } \\
\text { Osaka Gas } \\
\text { Urban Renaissance } \\
\text { Agency }\end{array}$ & $\begin{array}{c}\text { Kansai Electric } \\
\text { Power }\end{array}$ \\
\hline \multicolumn{3}{|c|}{$\begin{array}{l}\text { Efforts to modify and firmly inculcate local citizens' awareness and } \\
\text { behavior(Kyoto Prefecture and the Public Foundation of Kansai Research } \\
\text { Institutes) }\end{array}$} \\
\hline
\end{tabular}

(Source) This formation is taken from [16]. The interview was conducted on Feb 20, May 20, 2013.

*WG: Working Group. WG is the group of firms who works under the same theme. The HEMS and Electricity DR is an example of the in 8 WGs.

**Electricity DR: Electricity demand response.

In addition to HEMS and Electricity DR, the Kansai Science City Next-Generation Energy and Social Systems Demonstration Project Promotion Council has six Working Groups (WG) for CEMS (Community Energy Management System), BEMS (Building Energy Management System), the EV (Electric Vehicle) charge management system, the EV

\footnotetext{
${ }^{4}$ Kansai Science City Next-Generation Energy and Social Systems Demonstration Project Promotion Council has 8 WGs. The HEMS and Electricity DR are just 2 examples of 8 WGs.
}

Charging Network, V2X (a system to enable electric vehicles to charge other " $\mathrm{X}$ " systems at homes, commercial facilities, etc.), and advanced demonstration tests. Just two WG for HEMS and Electricity DR are included in Table I for relation of margin.

These support entities bring together a total of 26 firms and groups organized around the Promotion Council including Kyoto Prefecture that is the regional government of the demonstration test area. The various WGs, Promotion Committee meeting and Promotion Council meeting hold periodically, in which the theme-related firms and institutions participate. As a result, current issues and results of smart grid systems demonstration test are shared among the related firms and institutions.

\section{Organization for Promoting Demonstration Tests in Yokohama City}

The Next-Generation Energy and Social Systems Demonstration Project Promotion Council have organized in Yokohama City. The organizations formation is shown in Table II.

This organization was established by Yokohama City in 2010 when the city was selected as a demonstration area for the project.

\begin{tabular}{|c|c|}
\hline \multicolumn{2}{|c|}{$\begin{array}{l}\text { Promotion Council } \\
\text { Chair: General manager in Yokohama City } \\
\text { Members: Related firms }\end{array}$} \\
\hline $\begin{array}{l}\text { Promotion } \\
\text { Committee }\end{array}$ & $\begin{array}{c}\text { General manager in Yokohama City, } \\
\text { representatives of working groups, and related } \\
\text { firms }\end{array}$ \\
\hline WG & HEMS \\
\hline WG Leader & Toshiba \\
\hline Participating Firms & Panasonic and other firms \\
\hline
\end{tabular}

(Sources) This table is taken from the interview material [18]. The interview was conducted on July 12, 2013

The Yokohama Smart City Project Promotion Council shown in Table II is an organization established to promote the Next-Generation Energy and Social Systems Demonstration Project. There are four working groups (WGs) in the council: the HEMS, CEMS, BEMS, and transportation (because of the space is limited in this paper, Table II shows only the contents of the HEMS).

\section{E. Sharing Information about Demonstration Tests among Firms in Kansai Science and Yokohama Cities}

In Kansai Science and Yokohama Cities, information sharing among participating firms and institutions promoted through organizations consist of multiple levels hierarchies shown in Table I and Table II. These organizations have two roles.

First, the construction of the multiple levels hierarchies provide chance to share information among firms and institutions that belong to different levels of hierarchies. However, there need some factors that encourage information sharing under the current organization structure for developing each part of the smart grid system and whole system under the cooperation of the firms.

For bringing out the information sharing among firms, WGs meetings, Promotion Committee meeting and Promotion Council meeting are co-sponsored by regional government and participating firms in the demonstration test 
project. And Yokohama City also supports WG meetings, Promotion Committee meeting and Promotion Council meeting. Those are held periodically under the organizational structure on Table I and Table II. In addition to that each regional government works as a coordinator between participants.

For example, Kyoto prefecture administrative officers in Kansai Science City participated in every WG meetings, the Promotion Committee meeting and the Promotion Council meeting to understand the current situation and problems of demonstration test. Through this process, regional government can sum up and sorted out agendas with the original negotiation with firms for the Promotion Committee meeting which is higher than the WG meeting by one rank. However, the government administrative officer in demonstration test area is not always coordinates everything.

Specifically, with respect to the state of each firm's development status, demonstration status and future tasks are discussed among firms in WG meeting. In addition to that the information about attitude of the Promotion Council, METI, reaction of the residence participating in the demonstration test and the development process of each firm is shared relative firms in the WG meeting.

Officers of Kyoto prefecture and Yokohama City also participated in each WG meeting however, firms to lead the discussion.

Moreover, unsolved problems related technologies solved basically within a firm and problems related to interface are discussed among firms under the control of the WG leader.

With the respect to spec problems are solved based on the master plan and along with it firms have new roles to solve them. However, new request about spec from the government (METI) are discussed in the Promotion Committee meeting first, then it discussed within the WG meeting.

The information that flows in each WG meeting sum up by the WG leader and reported to the Promotion Committee meeting that consists of WGs leaders, the government of the demonstration test area (a specially appointed director and a manager in the cases of Kansai Science and Yokohama Cities, respectively), and related institutions. Therefore, the information about each WG's unresolved problem and current status of demonstration test is shared between hierarchies of the Project Promotion Council organization in both cities.

Through this process, information on the development process, the present state and problems of the demonstration test is shared not only in participating firms and institutions, but also in the government officers of the demonstration test area.

In addition to WG meetings and Promotion Committee meeting, Promotion Council meeting is held once a year. In Promotion Council, agendas about budget and direction of the demonstration are discussed and the result of the Promotion Committee meeting is reported.

Second, the construction of organization that consist of multiple levels of hierarchies promote demonstration test in two cities give the chance to sum up the information of each WGs. The information about current situation of the system development on each firm provided to the WG leader in organizations and they sum up that information and report it to METI with government administrative officers of the demonstration test region.

In this context, each firm in a WG meeting needs to make mutual communication about its own demonstration test's current situation. For reporting the current status of demonstration test to the METI, firms in the same WG bring data obtained in their own demonstration tests to the WG meeting, commonly understand what the data mean, and unify evaluation axes ${ }^{5}$.

In addition to above, for developing the smart grid system based on the master plan schedule, information sharing should be promoted among firms and regional government.

This case analysis reveals that not only firms and institutions which participated in the demonstration test, but also the government administrative officers of the demonstration test area make endeavor to promote information sharing within the demonstration test. The activities of the regional government, one of the organizer of the two cities' Demonstration Project Promotion Council and working as the coordinator become the one of the factors that promoting information sharing on demonstration test phase.

\section{CONCLUSION}

This paper examined socio-technical system demonstration tests and elucidated the factor and processes with which information sharing among participating firms can be achieved. For this purpose, demonstration tests on household sector in the cities of Kansai Science and Yokohama were analyzed and the actual status of information sharing among firms was investigated.

Consequently, it was revealed that regional government of the demonstration test area become the one of the organizer of the information sharing organizations which consist of multi levels hierarchies through which information sharing among participating firms could be achieved.

Moreover, the activity of each administrative officer in each demonstration test regions that participating in every meeting can promote information sharing among firms and institutions about current situation of the smart grid system development.

In addition, the activity of the regional government of the demonstration area who worked as a coordinator between stakeholders, between the residents, METI, participating firms and institutions, is to promote information sharing.

Thus, not only the firms' endeavor to share information to develop smart grid system, but also the activities of the regional government establishing the Project Promotion Council and having the role as the coordinator make it possible to promote each firm's information sharing.

\section{CONTRIBUTION AND IMPLICATIONS}

Existing literatures on the introduction and diffusion of socio-technical systems argued that for promoting the socio-technical system innovation, changing the stakeholders relationship originated in the multi-level hierarchies and the government supports are required [7], [9]-[13]. Moreover they assumed that the socio-technical system is already

\footnotetext{
${ }^{5}$ This takes from the interview with the administrative officer of Kansai Science City.
} 
developed to introduce and diffuse.

However, the government is not always come across the situation that can participated in the socio-technical system innovation and firms do not always confront the situation that new system already developed.

Thus, researches remain about the situation that the government can participate in the socio-technical system innovation and firms can communicate with other firms to develop and move to new system.

This paper suggests that under the situation the regional government of the demonstration test area can be sent into human resource to the demonstration test can promote socio-technical system demonstration test and information sharing among participators.

Second, under the situation the regional government of the demonstration test area exists as the organizer of an organizational structure and participator of the meetings could promote information sharing among firms and institutions on demonstration test phase.

This paper shows the possibility to previous literatures which have been focused on the external factors as influencing factors to promote socio-technical system innovation [7]-[13]. Making the situation such as having the organizational system for sharing information and creating the internal environment which make firms to concentrate on system development would be important for sharing information on socio-technical system development and promoting demonstration test.

\section{REFERENCE}

[1] S. Murakami "Welcome to the smart community," Ministry of Economy, Trade and Industry (METI), pp. 4-5, October/November, 2011.

[2] E. Trist, The Evolution of Socio-Technical System: a Conceptual Framework and an Action Research Program, Occasional paper No. 2, Ontario Ministry of Labour Ontario Quality of Working Life Center, Toronto Ontario, June 1981.

[3] D. Bonato and A. Schmutzler, "When do finns benefit from environmental regulations? A simple microeconomic approach to the porter controversy," Swiss Journal of Economics and Statistics (SJES), vol. 136, no. 4, pp. 513-530, 2000.

[4] H. Bulkeley and K. Kern, "Local Government and the Governing of Climate Change in Germany and the UK," Urban Studies, vol. 43, no. 12, pp. 2237-2259, 2006.

[5] J. Iio. (Aug. 9, 2010). Industrial systemization (11): The key breaking the barrier of the new creation is the social experience and the knowledge commoditizing. Mitsubishi Research Institution. Sangyou systemka (11): Shinsoujyouno kabewo toppa suru kagiwa shakai jikkento chino kyouyuka. [Online]. Available: http://www.mri.co.jp/NEWS/column/thinking/2010/2021009_1805.ht $\mathrm{ml}$

[6] M. Porter and C. van der Linde, "Toward a New Conception of the Environment-Competitiveness Relationship," The Journal of Economic Perspective, vol. 9, no. 4, pp. 97-118, 1995.

[7] G. Seyfang and A. Haxeltine, "Growing grassroots innovation exploring the role of community-based initiatives in governing sustainable energy transitions," Environment and Planning $C$ : Government and Policy, vol. 30, pp. 381-400, 2012

[8] P. Späth and H. Rohracher, "Energy regions': The transformative power of regional discourses on socio-technical futures," Research Policy, vol. 39, pp. 449-458, 2010.

[9] A. Tukker and M. Butter, "Governance of sustainable transitions: about the 4(0) ways to change the world," Journal of Cleaner Production, vol. 15, no. 1, pp. 94-103, 2007.

[10] F. Geels, Technological Transitions and System Innovations-A Co-evolutionary and Socio-Technical Analysis, Edward Elgar, Cheltenham, 2005

[11] F. Geels and J. Schot, "Typology of socio technical transition pathways," Research Policy, vol. 36, no. 3, pp. 399-417, 2007.

[12] G. Kallis and R. Norgaard, "Coevolutionary ecological economics," Ecological Economics, vol. 69, pp. 690-699, 2010.

[13] C. Sartorius, "Second-order sustainability conditions for the development of sustainable innovations in a dynamic environment," Ecological Economics, vol. 58, no. 2, pp. 268-286, 2006.

[14] Nikkei BP Clean Tech Institute press release "The announcement of the scale of the smart city energy demand network, Smart city enerugi kyoukyumouno shijyou kibowo happyou shimashita, 2012.

[15] F. Ikeda. (Dec.9, 2009). What is the smart grid? The basic things that we want to know about the next generation electronic networks. Two minutes Q\&A. Soft Bank Business IT. Smart grid towa nanika? Shite okitai jisedai denryoku networkno kihon, 2funkanno Q\&A, Soft Bank Business pulus IT. [Online]. Available: http://www.sbbit.jp/article/cont1/20638

[16] Keihanna (Kansai Science) Eco-city Next-Generation Energy and Social System Demonstration Project Promotion Council interview materials, 2013.

[17] Japan Smart City Portal. [Online]. Available: http://jscp.nepc.or.jp/en/index.shtml

[18] Yokohama City, "Yokohama Smart City Project (YSCP)," Yokohama City Promotion Council interview materials, July 2013.

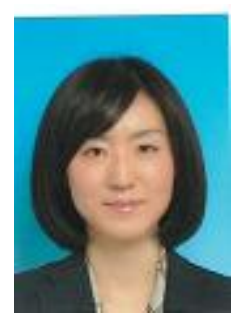

Youngjae Koh is currently an associated professor at the Hirao School of Management at Konan University, Hyogo, Japan. She graduated from Korea University. She received her M.A. and Ph.D in Business Administration from Hitotsubashi University in Tokyo, Japan, where she also worked as a junior fellow. She received the Takamiya award from the Organizational Science Conference (Soshiki Gakkai) in 2008 for best paper. 